\title{
Corrigendum
}

Genome Research 25: 1886-1892 (2015)

Corrigendum: Replication timing is regulated by the number of MCMs loaded at origins Shankar P. Das, Tyler Borrman, Victor W.T. Liu, Scott C.-H. Yang, John Bechhoefer, and Nicholas Rhind

The authors would like to correct the omission of Supplemental Tables S1-S4 from the final publication of this article. Please note that the Supplemental Tables have now been published online.

doi: 10.1101/gr.216945.116 


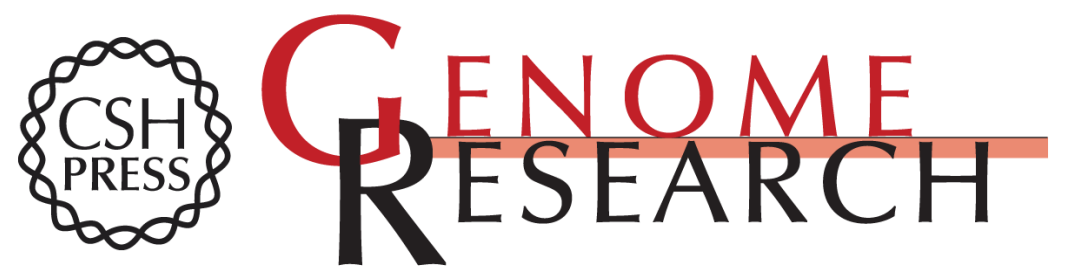

\section{Corrigendum: Replication timing is regulated by the number of MCMs loaded at origins}

Shankar P. Das, Tyler Borrman, Victor W.T. Liu, et al.

Genome Res. 2016 26: 1761

Access the most recent version at doi:10.1101/gr.216945.116

Related Content Replication timing is regulated by the number of MCMs loaded at origins

Shankar P. Das, Tyler Borrman, Victor W.T. Liu, et al.

Genome Res. December , 2015 25: 1886-1892

Open Access Freely available online through the Genome Research Open Access option.

License

Email Alerting Receive free email alerts when new articles cite this article - sign up in the box at the Service top right corner of the article or click here.

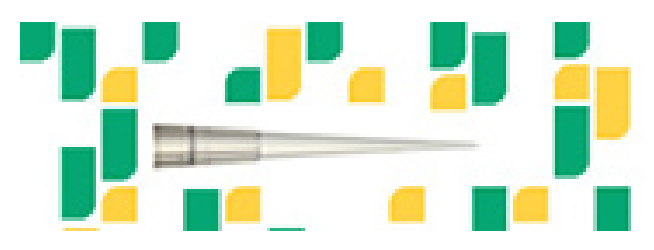

Focused on your science.

To subscribe to Genome Research go to:

https://genome.cshlp.org/subscriptions 